Journal of Advanced Research in Fluid Mechanics and Thermal Sciences

Journal homepage: www.akademiabaru.com/arfmts.html ISSN: 2289-7879

\title{
Biogas to Fuel Cell State of The Art: A Review
}

\author{
Shafini Mohd Shafie ${ }^{1 *}$, A Harits Nu'man² $^{2}$ Nik Nurul Anis Nik Yusuf ${ }^{3}$ \\ School of Technology Management and Logistics, College of Business, Universiti Utara Malaysia, 06010 Sintok, Kedah, Malaysia \\ Universitas Islam Bandung, West Java, Indonesia \\ Department of Energy, Minerals and Materials Technology, Universiti Malaysia Kelantan, 17600 Jeli, Kelantan, Malaysia
}

\section{ARTICLE INFO}

\section{Article history:}

Received 22 May 2021

Received in revised form 30 June 2021

Accepted 10 July 2021

Available online 13 August 2021

Keywords:

Life cycle assessment; fuel cell; electricity generation; Malaysia

\section{ABSTRACT}

Due to the emerging development in the energy industry, the demand for electricity consumption has sharply increased for each country. Therefore, a new recovery of energy resources is needed in consequence of the decreasing dependency on conventional energy resources, while sustaining energy security in the aspect of energy supply and climate change issues. The fuel cell is one of the most potential resources to be explored in order to overcome the constraints of the current energy generation. The aim of this paper is to discuss the entire cycle of the fuel cell system. It is starting from biogas production up to the recent studies related to life cycle assessment on fuel cell studies. Most of the researchers focused on the technical part of fuel cells; however, a comprehensive environmental assessment is essential to fully recognize the impact of fuel cells. Furthermore, this conceptual paper provided an idea on understanding the concept of fuel cell and referred to recently published articles related to life cycle assessment. Hopefully, this study can provide the guideline in determining the future energy for this country, in order to be less dependent on the current resources of energy supply.

\section{Introduction}

Energy security and climate change issues encouraged the world to explore alternatives resources in electricity generation. Global energy security is one of the key concerns as it depends on the stability of energy supplies from energy exporters [1]. The fuel cell is one potential renewable energy (RE) system that can generate electricity via sustainable methods. Currently, Korea had already generated electricity using fuel cells for 59MW of electricity capacity [2]. In the United States, the largest fuel cell facility has already operated with a capacity of $14.9 \mathrm{MW}$. Certain corporate buildings and commercial buildings in the US namely hospitals and shops have also begun operating using fuel cells from 200kW to $1 \mathrm{MW}$. Meanwhile in Japan, about 120,000 fuel cell units have been installed for residential application. Singapore believes that the consumption of hydrogen technologies such as fuel cell can achieve its ambitious goal towards the Sustainable Singapore Blueprint [3]. Indonesia has already signed a memorandum of understanding (MOU) with fuel cell developer, AFC Energy

\footnotetext{
* Corresponding author.

E-mail address: shafini@uum.edu.my
}

https://doi.org/10.37934/arfmts.86.1.87104 
which is based in the United Kingdom. Biomass resources are consumed to generate hydrogen gas for AFC Energy's fuel cells producing electricity [4]. In Thailand, the feasibility study indicated that the potential of solid oxide fuel cell to generate is about 1,069.42 $\mathrm{GWh} / \mathrm{yr}$ of electricity [5]. Even though fuel cell is quite new and still under the research and development phase in the ASEAN region, it is highly potential to become the future energy system. Nevertheless, in developed countries, the encouragement of fuel cells is heavily supported by the government through legislation and policy. Table 1 lists the development of worldwide fuel cell consumption.

\section{Table 1}

Development of worldwide fuel cell consumption [6]

\begin{tabular}{|c|c|c|}
\hline Country & Development & Target \\
\hline Austria & $\begin{array}{l}\text { Implemented regulation increased the market in fuel } \\
\text { cell consumptions. } \\
\text { Currently, Austrian stakeholders have already } \\
\text { implemented training of combined heat and power } \\
\text { (CHP) systems that use fuel cell system. }\end{array}$ & $\begin{array}{l}\text { Currently, the electricity supply is about } 32.5 \% \text {. } \\
\text { By } 2020 \text {, it is targeted to increase up to } 34 \% \text {. }\end{array}$ \\
\hline Denmark & $\begin{array}{l}\text { About } 20 \% \text { of government funding are channelled } \\
\text { towards hydrogen and fuel cell research and } \\
\text { development. }\end{array}$ & $\begin{array}{l}\text { By } 2050 \text {, the aim is to generate electricity totally } \\
\text { from renewable energy. }\end{array}$ \\
\hline Germany & $\begin{array}{l}\text { Focus on the stationary power output of } 5 \mathrm{~kW} \text { for } \\
\text { residential supply. } \\
\text { By } 2015,800 \text { units were installed as a demo project, } \\
\text { in energy and heating systems. } \\
1000 \mathrm{MW} \text { of fuel cell CHP have already operated } \\
\text { under 500,000 fuel cell heating appliances. }\end{array}$ & $\begin{array}{l}\text { By } 2050 \text {, it is targeted that the total energy } \\
\text { supply will be } 80 \% \text { from renewable energy. }\end{array}$ \\
\hline Italy & $\begin{array}{l}\text { The Regional Energy Plan already contains training } \\
\text { regarding fuel cell technologies specifically focusing } \\
\text { on the consumption of hydrogen fuel and } \\
\text { component system of generation up to distribution. }\end{array}$ & $\begin{array}{l}\text { Improving energy security and achieve } 20 \% \text { of } \\
\text { renewable energy consumption. }\end{array}$ \\
\hline Japan & $\begin{array}{l}\text { In } 2009 \text {, Japan has turned into the world's earliest } \\
\text { country that commercialised residential fuel cell } \\
\text { systems. } \\
\text { Then in } 2014 \text {, about } 70,000 \text { units of fuel cell were } \\
\text { operated in Japan. }\end{array}$ & $\begin{array}{l}\text { By } 2030 \text {, it is targeted that } 10 \% \text { of the } \\
\text { residential sector will consume energy from } \\
\text { stationary fuel cells that are equivalent to } 5.3 \\
\text { million units installed. }\end{array}$ \\
\hline $\begin{array}{l}\text { South } \\
\text { Korea }\end{array}$ & $\begin{array}{l}\text { Implemented the policies in terms of subsidies and } \\
\text { renewable portfolio standard (RPS). } \\
\text { These will motivate them to penetrate fuel cell to the } \\
\text { industries. Consequently, companies like POSCO } \\
\text { Energy and Hyundai Motors are moving towards fuel } \\
\text { cell consumption. } \\
\text { A subsidy is provided for installation costs up to } 50 \% \text {. }\end{array}$ & Target to consume $11 \%$ of RE by 2035 . \\
\hline Sweden & $\begin{array}{l}\text { For the development of fuel cell and hydrogen } \\
\text { projects, the government allocated EUR } 2 \text { million a } \\
\text { year. }\end{array}$ & $\begin{array}{l}\text { By } 2020 \text {, the aim for renewable energy } \\
\text { consumption is } 50 \% \text {, which consists of } 10 \% \text { from } \\
\text { the transportation sector, } 20 \% \text { from energy } \\
\text { efficiency and } 40 \% \text { from greenhouse gas (GHG) } \\
\text { emission reduction. }\end{array}$ \\
\hline $\begin{array}{l}\text { United } \\
\text { States of } \\
\text { America }\end{array}$ & $30 \%$ of tax credit for installed fuel cell system. & $\begin{array}{l}\text { By } 2023 \text {, to reduce } 3 \text { billion tons of cumulative } \\
\text { carbon emissions. }\end{array}$ \\
\hline
\end{tabular}


It seems that fuel cell technology has attracted many interests to be explored and utilised by combining it with available renewable energy resources. Therefore, this paper discusses the development of fuel cell including the type of fuel cell and biogas production in Malaysia that concentrates on technology and currently available biogas plants. Apart from that, it covers too about the life cycle assessment studies and recent studies on LCA that focus on the fuel cell.

\section{Development of Fuel Cell}

A fuel cell is an electrochemical component that provides electricity output from chemical energy that can be used in mobile and stationary applications. The inputs to the system are hydrogen gas or biogas and oxygen gas, while the outputs from the system are electricity and water. The type of fuel cell will determine the needed input gas and the output efficiency. There are seven types of the fuel cell, namely proton-exchange membrane fuel cell, direct methanol fuel cells, alkaline fuel cells, phosphoric acid fuel cells, molten carbonate fuel cells, solid oxide fuel cells, and reversible fuel cells based on Figure 1.

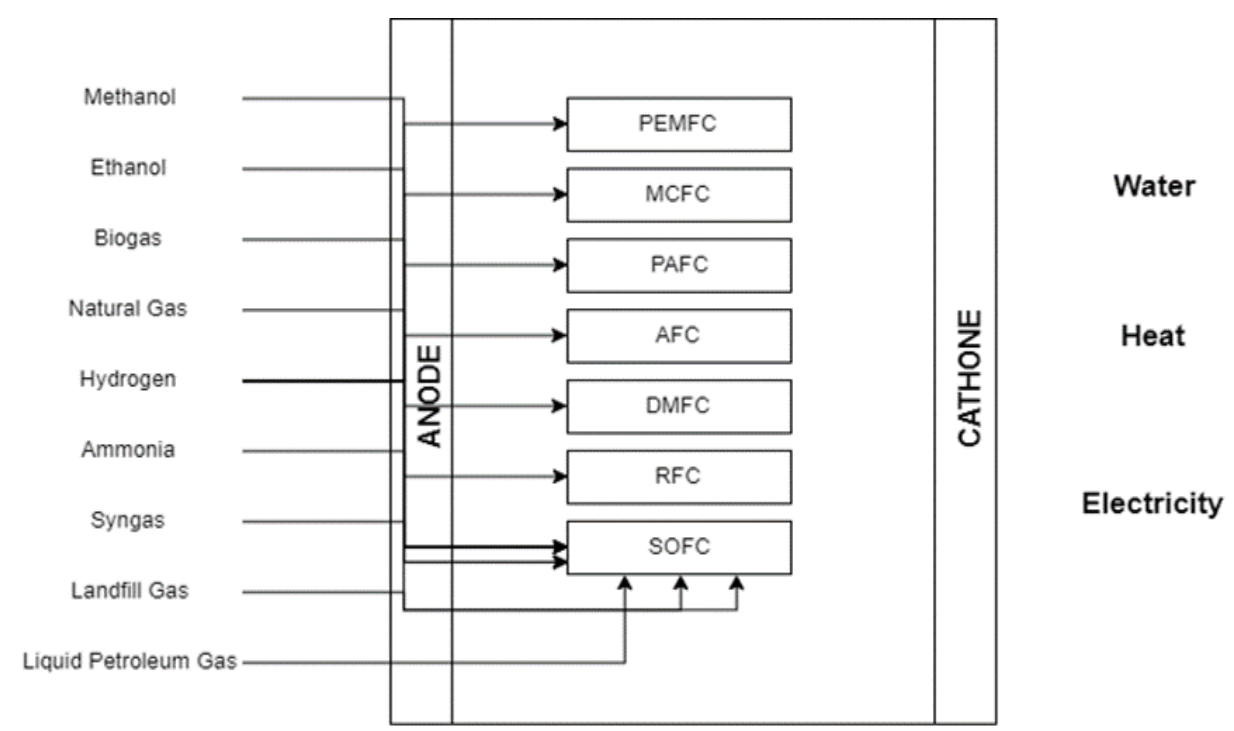

Fig. 1. Concept of a fuel cell system

The most common applications of fuel cell technologies are molten carbonate fuel cells (MCFC), solid oxide fuel cells (SOFC), and phosphoric acid fuel cells (PAFC). However, proton exchange membrane fuel cells (PEMFC) and alkaline fuel cells (AFC) have a small installation percentage that has been deployed to date [7].

\subsection{Solid Oxide Fuel Cell (SOFC)}

SOFCs are given higher efficiency up to $60 \%$ when transformed from chemical energy to electrical energy [8]. SOFCs have diverse fuel feeding systems that can inject natural gas, ammonia, hydrogen, methanol, biogas, synthesis gas etc. as input gas [9]. When it allows biogas feeding as input to the system, the emissions in terms of carbon dioxide $\left(\mathrm{CO}_{2}\right)$, nitrous oxide ( $\mathrm{NOx}$ ), and sulfur oxide ( $\mathrm{SOx}$ ) are lower as compared to the conventional boiler [10]. Research that studied biogas feeding [11] showed the result of applicable factors that could affect the overall efficiency of SOFC power plants. There is also a study that integrated SOFC with the pyrolysis-gasification process that generated electricity using a green treatment technique of plastic waste [12]. Rationally, if the fuel gas has 
carbon atoms, the fuel cell system output can emit carbon dioxide. However, the emission is called carbon-neutral if the fuel gas is originally from biomass resources [13]. The efficiency of the SOFC gasification system can go up to $43 \%$ based on experiments of commercialised gasification and the use of SOFC stack [14]. The fuel variety input of SOFCs permits flexible plants that can produce power with economically-friendly benefits that attract the market in terms of fuel price without any risk and impact to the environment [15].

\subsection{Microbial Fuel Cell (MFC)}

Microbial fuel cells (MFCs) are one of the technologies for the future due to the applicable systems that consume wastewater to generate electricity. Its design factor allows the biological process to be directly converted to electrical power [16]. MFCs is one of the most promising methods to generate green energy [17].

\subsection{Proton Exchange Membrane Fuel Cell (PEMFC)}

This type of fuel cell is capable of establishing technology for combined heat and power plants [18]. Even though the study on fuel cell technology can be easily found in the journal (Table 2), the focus on life cycle assessment is still limited. Since fuel cell application in the Malaysian industries is still in its early stage, evaluating the entire life cycle of the system is probable to measure which component of the process offers the most significance towards environmental weight. Besides, it is needful to search for potential results towards achieving an environmental performance developments [21].

\section{Table 2}

Lists of most available type of fuel cell for combination with the biomass power plant

\begin{tabular}{llll}
\hline Fuel Cell Type & Biomass Type & Description & Ref \\
\hline SOFC & $\begin{array}{l}\text { Wood chips. } \\
\text { SoFC }\end{array}$ & $\begin{array}{l}\text { Efficiencies up to } 62 \% \text { when used gasification with combined SOFC. } \\
\text { solid waste. }\end{array}$ & Model of syngas fueled to the system. \\
SOFC & $\begin{array}{l}\text { Use ammonia as fuel to SOFC, generate } 100 \mathrm{~kg} / \text { day of hydrogen } \\
\text { (equivalent to energy for fueling up to 20-30 fuel cell vehicles) as well } \\
\text { as fast-charging electric vehicle and heat for local consumption. }\end{array}$ \\
\hline
\end{tabular}

\section{Biogas Production in Malaysia}

Malaysia generates a huge potential in biogas production due to the abundance of biomass resources especially oil palm [22]. Palm oil waste is potentially proposed in biogas production among many other varieties of biomass types that exist. Figure 2 shows the variety of biomass production in Malaysia. 


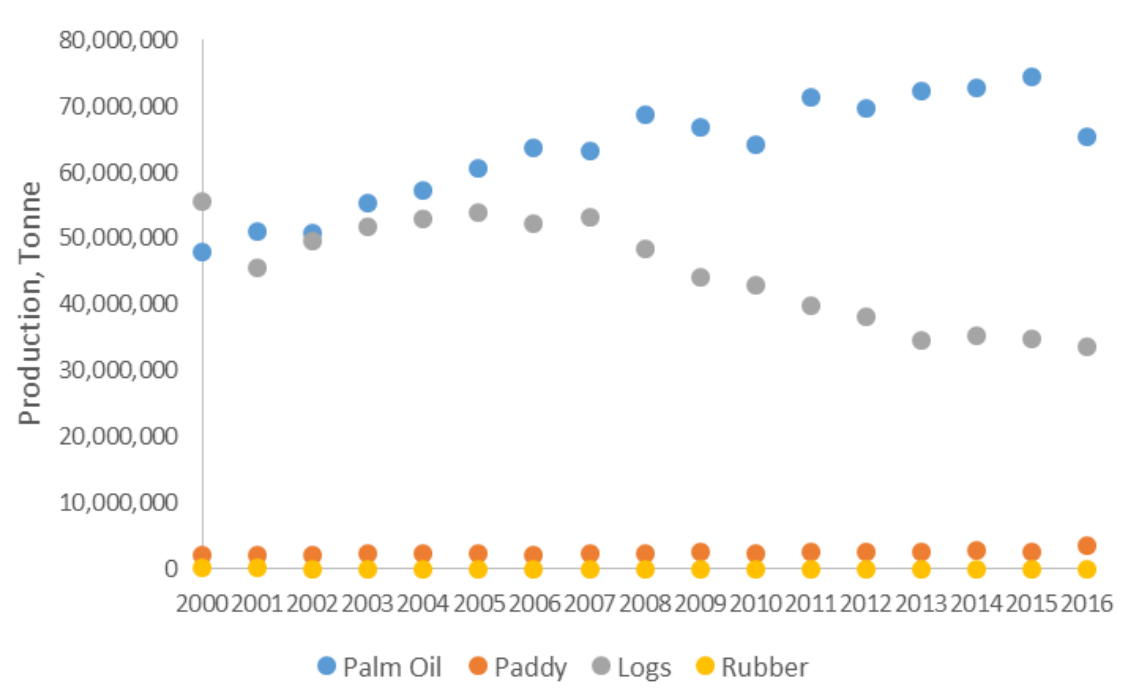

Fig. 2. Variety of biomass production in Malaysia

Figure 3 displays the waste production from palm oil mills in Malaysia. The type of wastes from mills such as palm oil mill effluent (POME), empty fruit bunch (EFB), palm fibre and palm shell are potentially applied in generating biogas. Therefore, an appropriate waste management system in palm oil mills can provide a clean and sustainable environment [23]. According to Shafie et al., [24], by 2030 , Malaysia has the potential to generate about $1474 \mathrm{MW}$ of electricity by using biogas resources. This is expected to fulfil Malaysia's National Renewable Energy Policy that targets $20 \%$ of renewable energy in mixing energy generation towards 2030. One way to achieve this is by enabling greater access to renewable energy sources. Other policies that encourage biogas production as energy resources are the Renewable Energy Act 2011 and Sustainable Development Energy Act 2011. Malaysia also has the National Biofuel Policy that aims to establish the consumption of biodiesel. In total, Malaysia has nine policies that are all related to the penetration of RE and strengthening energy security for sustainability purposes [25]. As the government strengthens the biogas industry, it is forecasted that this sector will contribute about RM20.2 billion to Malaysia's bioeconomy by 2020. The price of biomass per tons in the National Biomass Strategy study is RM200 per dry ton or equivalent to USD56 per dry ton [26].

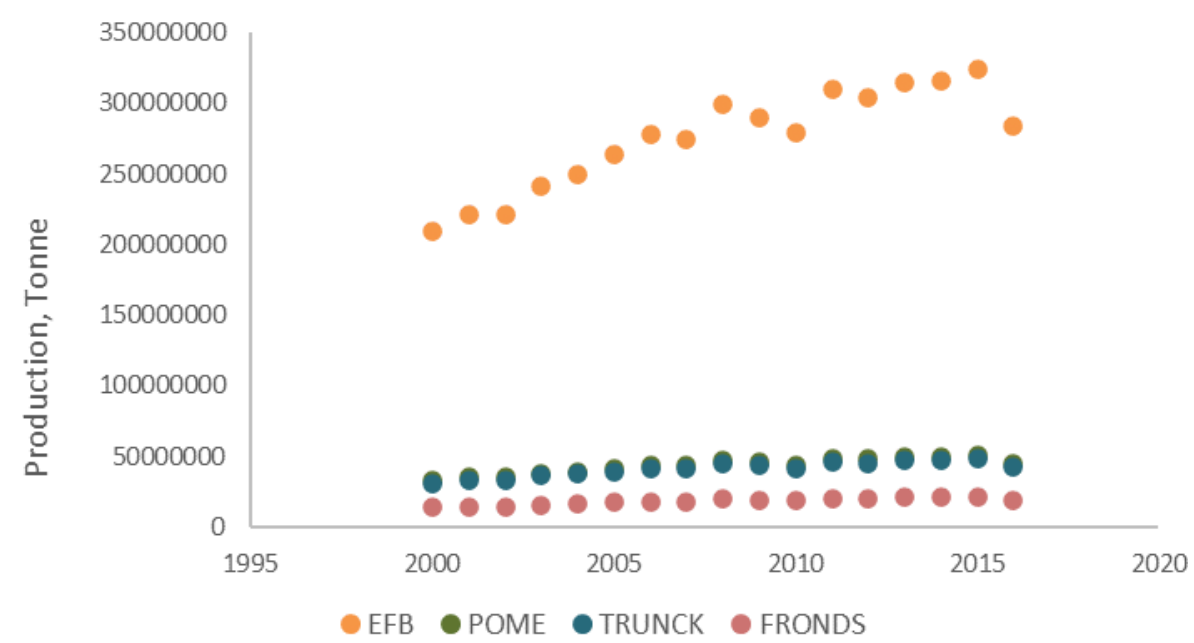

Fig. 3. Waste production from palm oil mills in Malaysia 
Biogas is a biofuel that is produced from the microbial fermentation of organic waste [23]. It is a gas that is produced by the organic substrates under the anaerobic environment, among the complicated organic matter that is decomposed by anaerobic bacteria. The components inside the biogas are methane (55\% to $70 \%)$, carbon dioxide (30\% to $45 \%)$, and other traces of gases such as oxygen, carbon monoxide, and hydrogen sulphide. The smell of biogas is like the stench of rotten eggs; nevertheless, after desulfurisation, the smell is not easily perceptible. The raw materials to produce biogas are organic wastes such as biomass, animal waste, and wastewater. There are several commercialised techniques to produce biogas like anaerobic digestion and gasification.

\subsection{Anaerobic Digestion}

Anaerobic digestion is one of the thermal processes. It is a biological method that turns biodegradable matters into methane and carbon dioxide by numerous microorganisms in the environment without oxygen [27]. There are four stages in anaerobic digestion namely hydrolysis, acidogenesis, acetogenesis, and methanation [27]. Figure 4 shows the degradation steps of the anaerobic digestion process for palm oil waste [28].

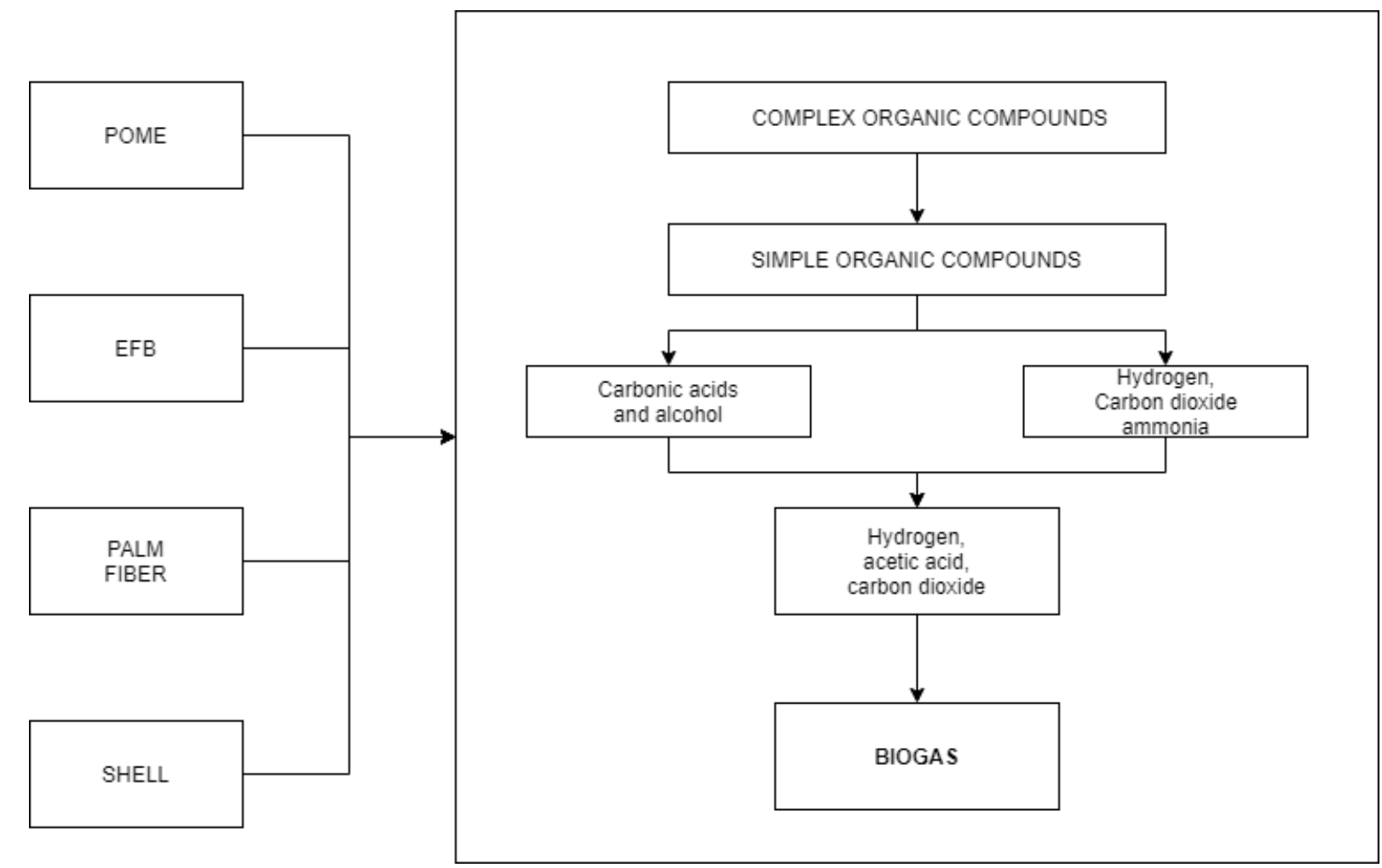

Fig. 4. Degradation steps of the anaerobic digestion process [28]

The hydrolysis stage is a chemical decomposition process that uses water to decompose chemical bonds of organic matter [29]. The acidogenesis stage ferments soluble matter produced by hydrolysis and generates volatile fatty acids (VFAs), carbon dioxide, hydrogen gas, and alcohols [30]. Acetogenesis is the process in which acetate is formed by reducing carbon dioxide from an organic acid. As for methanation, it is the process of methane generation from carbon dioxide and hydrogen, formate, alcohols, and methylated $\mathrm{C}_{1}$ compounds [31].

Pecchi and Baratieri [32] stated that anaerobic digestion can recover energy from biomass which is completed by collecting the biogas from the waste stream produced by the bacteria. Besides, anaerobic digestion can produce valuable fertilisers which is the digest with improved properties 
relative to untreated biomass. Anaerobic digestion can reduce agricultural and industrial wastes because they contain easily biodegradable materials to be decomposed. At the same time, it can decrease the usage of fossil fuels [33].

\subsection{Gasification}

Gasification is a conversion process from carbonaceous materials like coal and agricultural waste to syngas and can be used to generate electricity or other products such as chemical products, fuels and fertilisers [34]. Ng'andwe et al., [35] defined gasification as a thermochemical process that turns biomass into gases to be used for multiple purposes. Gasification does not have combustion inside the closed reactor, but it uses a low amount of oxygen to change carbon-based materials into syngas.

There are several reactions occurring simultaneously in the gasification process which are drying, pyrolysis, oxidation and reduction [36]. The first step of gasification is drying, in which the water leaves the coal particles in the form of steam [37]. Then, the pyrolysis step involves heating the fuel in the absence of air to produce charcoal and tar gases [38]. Oxidation adds air and combines oxygen with the gases to produce waste products such as vapour and carbon dioxide [38]. Finally, the oxygen will be removed from waste products at high temperature to produce flammable gas [38].

The gas produced by gasification can be used to start up gasoline or diesel engines once completed with the cleaning and purification process. Moreover, it can be used to produce biofuel or generate electricity through gas engine, gas or steam turbine [35]. Besides, gasification will decompose the carbonaceous materials to the molecular level. Therefore, the impurities such as nitrogen and sulphur will be removed and become valuable industrial products [33].

\subsection{Current Biogas Plants in Malaysia}

Table 3 indicates the current biogas mill production in Malaysia. Most of these mills are using anaerobic digestion to produce biogas. These techniques constitute the process of biodegradable organic wastes. It is currently being practice in the palm oil industry and commonly applied in Malaysia due to cost-effectiveness and attractiveness of the method in relation to waste management and treatment [23-39]. Output biogas is used in electricity generation up to $2 \mathrm{MW}$ per power plant. In 2012, about 36 out of 58 palm oil mills had already registered for biogas recovery under Clean Development Mechanism (CDM) projects. Report regarding the registered mills can be referred on the National Key Economic Area (NKEA) [40]. The data showed an increasing pattern. In 2016, about 92 biogas plants were already in operation. Further, an additional 9 plants were under construction and 145 plants were in various planning stages [41]. Malaysia has the huge potential to be one of the major contributors of renewable energy through palm oil biomass and biogas production [42]. However, in biogas production for power generation, there are limitations in using biogas as fuel due to low caloric value and impurities constraint. Besides, some technologies are still under research and development in local universities, thus it directly reduces the confidences of the stakeholders to invest in biogas power plants here [43]. Furthermore, Malaysia is still lacking in local anaerobic digestion technology due to the challenges in the deployment of biogas upgrading and injection [44]. The most challenging process on plant performance is related to the power system design and pre-conditioning process. 
Table 3

Current biogas plants in Malaysia [45]

\begin{tabular}{|c|c|c|c|c|c|}
\hline Name & Description & Location & $\begin{array}{l}\text { Capacity } \\
(\mathrm{MW})\end{array}$ & Technology & $\begin{array}{l}\text { Cost } \\
\text { (RM Million) }\end{array}$ \\
\hline $\begin{array}{l}\text { Havys Oil Mill } \\
\text { Sdn Bhd }\end{array}$ & $\begin{array}{l}\text { Using REGEN System (Waste } \\
\text { Recovery and Regeneration System } \\
\text { [33]. } \\
\text { The largest grid-connected palm oil } \\
\text { mill effluent biogas plant in } \\
\text { Malaysia is Cenergi. }\end{array}$ & $\begin{array}{l}\text { Palong, Negeri } \\
\text { Sembilan } \\
\text { Pahang }\end{array}$ & 12.5 & $\begin{array}{l}\text { Anaerobic } \\
\text { digestion. }\end{array}$ & \\
\hline $\begin{array}{l}\text { Pantai Remis } \\
\text { Biogas Power } \\
\text { Plant, Perak }\end{array}$ & $\begin{array}{l}\text { Carbon Savings: } 1,153 \text { tons. } \\
\text { Typically, around } 800 \mathrm{~m}^{3} \text { of raw } \\
\text { biogas per hour. } \\
\text { Total Households Powered: } 2,600 \\
\text { households ( } 500 \mathrm{KWh} \text { per } \\
\text { household). }\end{array}$ & Perak & 1.5 & $\begin{array}{l}\text { In-ground } \\
\text { anaerobic } \\
\text { digester. }\end{array}$ & 12 \\
\hline $\begin{array}{l}\text { Cheekah Biogas } \\
\text { Power Plant, } \\
\text { Malaysia. }\end{array}$ & $\begin{array}{l}\text { Carbon Savings: } 16,602 \text { tons } \mathrm{CO}_{2 \text { eq. }} \\
\text { Total Households Powered: } 2,160 \\
\text { ( } 540 \text { MWh per month). } \\
\text { The plant produced } 600-750 \mathrm{~m}^{3} \\
\text { of raw biogas per hour. }\end{array}$ & & 1 & & 8.6 \\
\hline \multirow[t]{2}{*}{$\begin{array}{l}\text { Sri Jelutung } \\
\text { Biogas Power } \\
\text { Plant, Malaysia. }\end{array}$} & $\begin{array}{l}\text { Carbon Savings: } 24,903 \text { tons } \mathrm{CO}_{2 \text { eq. }} \\
\text { Total Households Powered: } 3,200 \\
\text { ( } 800 \text { MWh per month). }\end{array}$ & & 1.5 & $\begin{array}{l}\text { In-ground } \\
\text { anaerobic } \\
\text { digester. }\end{array}$ & 11 \\
\hline & $\begin{array}{l}\text { Carbon Savings: } 16,602 \text { tons } \mathrm{CO}_{2 \text { eq. }} \\
\text { Total Households Powered: } 2,160 \\
\text { ( } 540 \text { MWh per month). } \\
\text { The plant produced } 600-750 \mathrm{~m}^{3} \\
\text { of raw biogas per hour. }\end{array}$ & $\begin{array}{l}\text { Sawira Biogas } \\
\text { Power Plant, } \\
\text { Malaysia }\end{array}$ & 1 & & 8.6 \\
\hline \multirow[t]{3}{*}{$\begin{array}{l}\text { Havys Biogas } \\
\text { Power Plant, } \\
\text { Malaysia } \\
\text { Palm Oil Waste } \\
\text { Energy } \\
\text { Resources Sdn. } \\
\text { Bhd. }\end{array}$} & $\begin{array}{l}\text { Carbon Savings: } 33,204 \text { tons } \mathrm{CO}_{2 \text { eq. }} \\
\text { Total Households Powered: } 4,000 \\
\text { ( } 1,080 \text { MWh per month). } \\
\text { The process produces biogas, } \\
\text { which can be reused to generate } \\
\text { electricity for the running of the } \\
\text { plant. }\end{array}$ & & 2 & & 18 \\
\hline & $\begin{array}{l}\text { In progress to export electricity } \\
\text { into a system grid with a capacity } \\
\text { of } 1 \mathrm{MW} \text {. }\end{array}$ & $\begin{array}{l}\text { Cheekah- } \\
\text { Kemayan Palm } \\
\text { Oil Mill (GLT } \\
\text { Energy Sdn Bhd) }\end{array}$ & 1 & $\begin{array}{l}\text { In-ground } \\
\text { biogas } \\
\text { reactor. }\end{array}$ & \\
\hline & $\begin{array}{l}\text { EPCC for In-Ground Biogas. } \\
\text { Status: In progress. }\end{array}$ & $\begin{array}{l}\text { Taclico Palm Oil } \\
\text { Mill (GLT Bio } \\
\text { Sdn Bhd } \\
\text { Kulim, Kedah }\end{array}$ & 1 & & \\
\hline $\begin{array}{l}\text { Rompin Palm } \\
\text { Oil Mill (GLT } \\
\text { Renewable Sdn. } \\
\text { Bhd.) }\end{array}$ & $\begin{array}{l}\text { In-ground biogas reactor. } \\
\text { In progress. }\end{array}$ & Rompin & 2 & & \\
\hline $\begin{array}{l}\text { Setia Kawan } \\
\text { Palm Oil Mill } \\
\text { (GLT Eco Sdn. } \\
\text { Bhd.) }\end{array}$ & In-ground biogas. & Kulim, Kedah & 2 & & \\
\hline
\end{tabular}


Table 3 (continued)

\begin{tabular}{|c|c|c|c|c|c|}
\hline Name & Description & Location & $\begin{array}{l}\text { Capacity } \\
\text { (MW) }\end{array}$ & Technology & $\begin{array}{l}\text { Cost } \\
\text { (RM Million) }\end{array}$ \\
\hline $\begin{array}{l}\text { Sawira Makmur } \\
\text { Palm Oil Mill } \\
\text { (GLT Energy } \\
\text { Sdn. Bhd.) }\end{array}$ & $\begin{array}{l}\text { In progress to export electricity } \\
\text { into a system grid with a capacity } \\
\text { of } 1 \mathrm{MW} \text {. }\end{array}$ & $\begin{array}{l}\text { Bandar } \\
\text { Muadzam Shah, } \\
\text { Pahang }\end{array}$ & 1 & & \\
\hline $\begin{array}{l}\text { Felda Bukit Sagu } \\
\text { Palm Oil Mill }\end{array}$ & $\begin{array}{l}\text { In-ground biogas reactor. } \\
\text { Status: In operation. } \\
\text { Biogas storage of } 25,000 \mathrm{~m}^{3} \text { for } \\
\text { power generation. }\end{array}$ & $\begin{array}{l}\text { Kuantan, } \\
\text { Pahang }\end{array}$ & & & \\
\hline $\begin{array}{l}\text { Mukah Palm Oil } \\
\text { Mill }\end{array}$ & $\begin{array}{l}\text { In-ground biogas reactor. } \\
\text { In operation. } \\
\text { Biogas production of } 1000 \mathrm{~m}^{3} \text {. }\end{array}$ & Mukah, Sarawak & & & \\
\hline $\begin{array}{l}\text { Sri Jelutong } \\
\text { Palm Oil Mill }\end{array}$ & & Pekan, Pahang & 1.2 & & \\
\hline $\begin{array}{l}\text { Havys Palm Oil } \\
\text { Mill }\end{array}$ & $\begin{array}{l}\text { In-ground biogas reactor, } \\
\text { engineering design and testing and } \\
\text { commissioning consultancy. }\end{array}$ & Palong, Pahang & 2 & & \\
\hline $\begin{array}{l}\text { Rinwood Palm } \\
\text { Oil Mill }\end{array}$ & $\begin{array}{l}\text { In-ground biogas storage system. } \\
\text { Status: In operation. } \\
\text { Biogas storage of } 1,200 \mathrm{~m}^{3} \text {. }\end{array}$ & Mukah, Sarawak & & & \\
\hline $\begin{array}{l}\text { Sg Kahang Palm } \\
\text { Oil Mill }\end{array}$ & $\begin{array}{l}\text { In-ground biogas storage system. } \\
\text { Biogas storage of } 17,000 \mathrm{~m}^{3} \text {. }\end{array}$ & $\begin{array}{l}\text { Sungei Kahang, } \\
\text { Johor }\end{array}$ & & & \\
\hline $\begin{array}{l}\text { Prosper Palm } \\
\text { Oil Mill }\end{array}$ & $\begin{array}{l}\text { Anaerobic Reactor. } \\
\text { Generating } 1 \mathrm{MW} \text { of electrical } \\
\text { power for the mill's kernel crushing } \\
\text { plant. }\end{array}$ & $\begin{array}{l}\text { Bandar Seri } \\
\text { Jempol, Negeri } \\
\text { Sembilan }\end{array}$ & 1 & & \\
\hline
\end{tabular}

\section{Life Cycle Assessment Studies}

Based on previous studies on LCA of fuel cells, it is found that feeding biogas into fuel cells can reduce the environmental impact [21-46]. Recently, most literature related to the LCA of fuel cell systems only concentrated on the manufacturing process and limited studies focused on gas feeding in their system boundary [10]. According to Rillo et al., [10], a wider environmental assessment is requisite to completely comprehend the impact of the biogas-fed SOFC system and its application. Aziz et al., [23], stated that there is still no available LCA study that is conducted to specifically focus on biogas production in Malaysia. Therefore, this paper aims to review the available LCA that applies solid oxide fuel cell feed with biogas considering all the stage involved.

\subsection{LCA Methodology Standard}

Life cycle assessment or LCA is an established method in accessing the environmental impact of a product or service. According to Staffell and Andy [47], LCA is an instrument to analyse and determine the environmental impacts of services and products for the entire life cycle ("cradle-tograve approach"). LCA starts from the material or fuel searching up to the production and disposal or recycling of the inspected objects. The international standards that mainly related to LCA are Environmental Management - Life Cycle Assessment - Principles and Framework (ISO 14040) and Environmental Management - Life Cycle Assessment - Requirements and Guidelines (ISO 14044). The main process related to LCA is (1) goal and scope, (2) life cycle inventory analysis, (3) impact assessment, and (4) interpretation. Figure 5 shows the LCA framework [48-49]. 


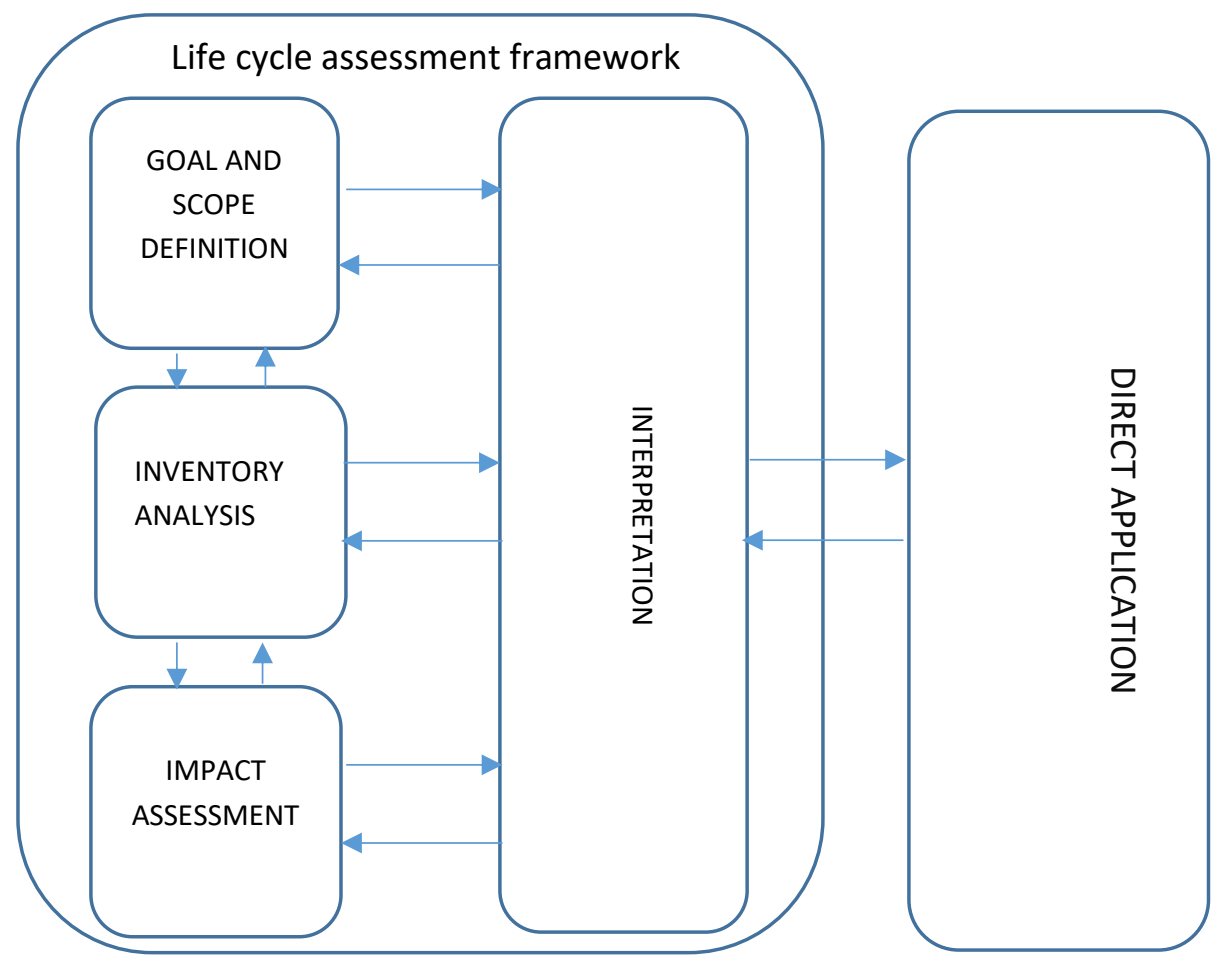

Fig. 5. Life cycle assessment framework [48-49]

\subsection{Goal and Scope}

Goal and scope can be defined as the initial stage that decides the planning or target for the LCA study. These can be generated from the exact question, target audience and proposed request. The level of complexity of the LCA study entirely reflects the set goal. Meanwhile, the scope of the study is definite in terms of sequential, geographic and technical analysis.

\subsection{System Boundary}

Recent literature on the LCA of fuel cell systems focuses on the manufacturing phase [10]. Figure 6 shows the possible system boundary in the life cycle of a product [50].

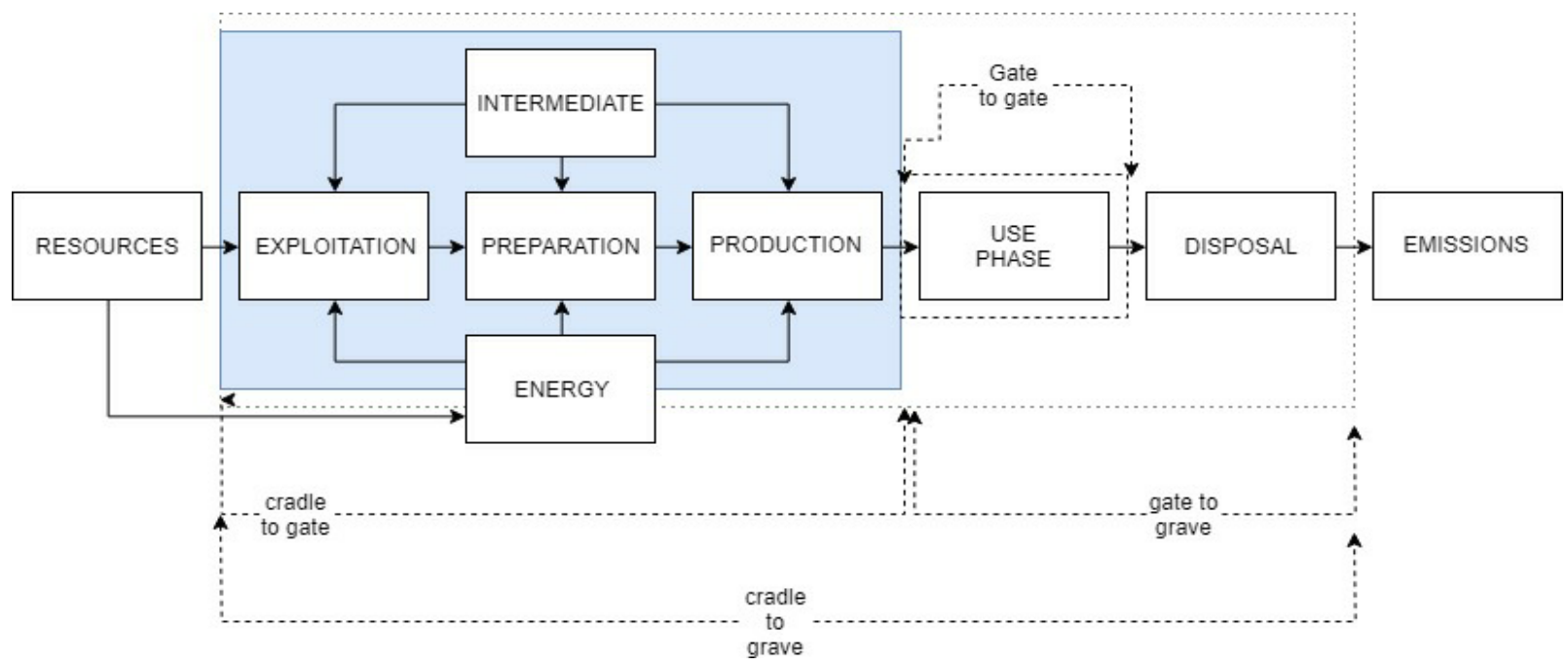

Fig. 6. Possible system boundary in the life cycle of a product [50] 
Basically, there are three types of the application system boundary namely (i) cradle-to-gate up to production only; (ii) gate-to-grave from the production or manufacture to disposal or recycling; and (iii) cradle-to-grave from resources to disposal. As an example, the system boundaries applied in this paper contain biogas generation and fabrication of SOFC, the system operation and maintenance that is suited for the "cradle-to-gate" approach [9]. To study the life cycle of biogas feed fuel cell, it can be started with supplementing the feedstock, biogas production and biogas utilisation, which is feed to fuel cells. This is identical with the study on biogas production for power generation that used CHP (combined heat and power plant) concept [51]. This paper has also set its system boundary starting from feedstock, feedstock transport, fuel processing, fuel distribution, and electricity generation that consist of the SOFC system [52]. However, most of the papers were more focused on fuel cell manufacturer instead of biogas production. Inside the system boundary, biogas production was simplified to become only one process [9]. Rillo et al., [10] only focused on the digestion process.

\subsection{Inventory Analysis}

The purpose of inventory analysis is to define the production system such as setting the system boundaries, planning the flow diagrams of unit processes, data collection for each process, execution allocation stages for multifunctional processes, and finalising the calculations. The key result in an inventory table lists the quantified inputs from and outputs to the environment-related with the functional unit, for example in terms of $\mathrm{kg}$ of carbon dioxide, $\mathrm{kg}$ of iron ore, $\mathrm{kg}$ of iron ore, cubic metres of natural gas, $\mathrm{mg}$ of phenol, etc. There are a few papers that listed out the output and input for their LCA process and the examples are 5kW SOFC [53], $100 \mathrm{~kW}$ [54] and 250kW [9]. These data are applicable for SOFC manufacturing and balance of plant within the SOFC systems.

\subsection{Impact Assessment}

Inventory analysis is purely the inventory table that is managed and interpreted in relation to the environmental and societal impacts. The outcome from this is a list of impact categories. The selected impact categories related to the environmental interventions that suit the category indicators. The definite model results are planned in the characterisation step. Optional normalization aid to specify the part of the modelled results in a worldwide or regional total. Lastly, the category indicator results can be grouped and weighted to comprise societal preferences of the numerous impact categories. Table 4 indicates the impact assessment for different articles that focused on LCA of fuel cell [9-1046-53-58]. Significantly, two indicators of mostly analysis impact categories are global warming potential (GWP) and acidification potential (AP) [55]. 
Table 4

Previous studies on LCA of solid oxide fuel cell

\begin{tabular}{|c|c|c|c|c|c|c|c|c|c|}
\hline \multirow[t]{2}{*}{ Impact Assessment } & \multicolumn{9}{|c|}{ References } \\
\hline & {$[10]$} & [56] & [9] & [55] & [54] & [57] & {$[58]$} & [46] & [53] \\
\hline Climate change & $\mathrm{V}$ & $\mathrm{V}$ & $\mathrm{V}$ & $\mathrm{V}$ & $\mathrm{V}$ & $\mathrm{V}$ & $\mathrm{V}$ & $\mathrm{V}$ & $\sqrt{ }$ \\
\hline Fossil depletion & $\mathrm{V}$ & V & V & & $\mathrm{V}$ & $\mathrm{V}$ & & & \\
\hline Acidification potential & $\mathrm{V}$ & $\mathrm{V}$ & & $\mathrm{V}$ & $\mathrm{V}$ & V & & $\mathrm{V}$ & $\mathrm{V}$ \\
\hline Photochemical oxidant formation & $\mathrm{V}$ & $\mathrm{V}$ & $\mathrm{V}$ & $\mathrm{V}$ & $\mathrm{V}$ & v & & $\mathrm{V}$ & $\mathrm{V}$ \\
\hline Particulate matter formation & $\mathrm{V}$ & & $\mathrm{V}$ & & $\mathrm{V}$ & & & & \\
\hline Ozone-depleting gases & & $\mathrm{V}$ & & $\mathrm{V}$ & $\mathrm{V}$ & $\sqrt{ }$ & & $\mathrm{V}$ & $\mathrm{V}$ \\
\hline Eutrophication & & $\mathrm{V}$ & & $\mathrm{V}$ & $\mathrm{V}$ & $\sqrt{ }$ & & $\mathrm{V}$ & \\
\hline Human toxicity & & & $\mathrm{V}$ & & $\mathrm{V}$ & $\mathrm{V}$ & & & \\
\hline Water depletion & & & $\mathrm{V}$ & & & & & & \\
\hline Ionising formation & & & & & $\mathrm{V}$ & $\mathrm{V}$ & & & \\
\hline Eco toxicity & & & & & $\mathrm{V}$ & V & & & \\
\hline Agriculture land occupation & & & & & $\mathrm{V}$ & & & & \\
\hline Metal depletion & & & & & $\mathrm{V}$ & & & & \\
\hline Abiotic depletion & & & & & & & & $\mathrm{V}$ & \\
\hline
\end{tabular}

\subsection{Interpretation}

Interpretation is the stage where the outcomes of the analysis, selection, and assumptions prepared through the development of the analysis, are assessed in terms of soundness and robustness leading to general decisions been drawn. The focal fundamentals of the interpretation phase are an evaluation of results, an analysis of outcomes and finally, designing the decision or conclusions which include recommendations of the study.

\section{Recent Studies on Life Cycle Assessment of Fuel Cell}

Most studies involved in Table 5 were specifically focused on fuel cell manufacturer by applying the gate-to-gate concept. None of the studies included the resources or production as the initial process in the setting of the system boundary. A majority of the LCA studies were related to solid oxide fuel cell due to the flexibility of fuel intake and its economic viability. Their wide range of applications in power generation included both stationary and portable aspects [59]. 


\section{Table 5}

Studies on life cycle assessment of fuel cell

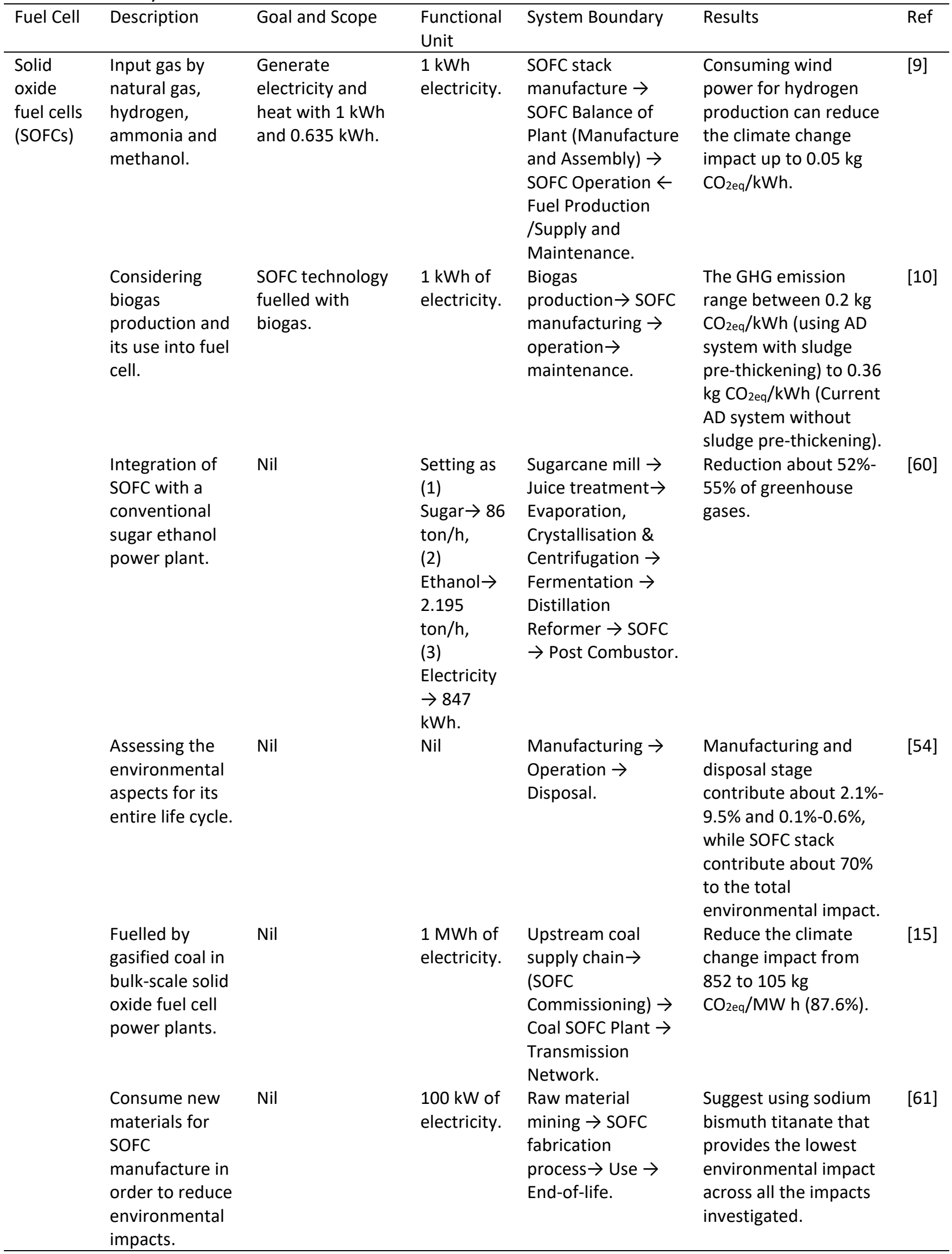


Table 5 (continued)

\begin{tabular}{|c|c|c|c|c|c|c|}
\hline Fuel Cell & Description & Goal and Scope & $\begin{array}{l}\text { Functional } \\
\text { Unit }\end{array}$ & System Boundary & Results & Ref \\
\hline \multirow[t]{2}{*}{$\begin{array}{l}\text { Solid } \\
\text { oxide } \\
\text { fuel cells } \\
\text { (SOFCs) }\end{array}$} & $\begin{array}{l}\text { Focus on the } \\
\text { interaction } \\
\text { between the } \\
\text { manufacturing } \\
\text { stages of the } \\
\text { life cycle. }\end{array}$ & $\begin{array}{l}\text { Identifying the } \\
\text { key } \\
\text { manufacturing } \\
\text { stages of the fuel } \\
\text { cell system. }\end{array}$ & $\begin{array}{l}1 \mathrm{~kW} \text { of } \\
\text { electricity }\end{array}$ & $\begin{array}{l}\text { Stack } \rightarrow \text { System } \\
\text { assembly } \leftarrow \\
\text { Balance of plant. }\end{array}$ & $\begin{array}{l}\text { The whole supply chain } \\
\text { of fuel cell system } \\
\text { provides significant } \\
\text { contribution towards } \\
\text { the overall } \\
\text { environmental impact. }\end{array}$ & {$[62]$} \\
\hline & $\begin{array}{l}\text { Fuelled with } \\
\text { natural gas and } \\
\text { fed with biogas } \\
\text { is compared of } \\
\text { the } \\
\text { environmental } \\
\text { impact. }\end{array}$ & Nil & $\begin{array}{l}1 \mathrm{~kW} \text { h net } \\
\text { of } \\
\text { electricity. }\end{array}$ & $\begin{array}{l}\text { Fuel cell supply } \rightarrow \\
\text { Fuel cell } \\
\text { manufacturing } \rightarrow \\
\text { Fuel cell } \\
\text { operation } \rightarrow \text { Fuel } \\
\text { cell end-of life. }\end{array}$ & $\begin{array}{l}\text { Provide positive } \\
\text { impacts towards } \\
\text { abiotic depletion, } \\
\text { eutrophication, global } \\
\text { warming, ozone layer } \\
\text { depletion and primary } \\
\text { energy demand as } \\
\text { compared to } \\
\text { conventional } \\
\text { resources. }\end{array}$ & [46] \\
\hline \multirow[t]{4}{*}{$\begin{array}{l}\text { Molten } \\
\text { carbonat } \\
\text { e fuel } \\
\text { cell }\end{array}$} & $\begin{array}{l}\text { LCA of molten } \\
\text { carbonate fuel } \\
\text { cell, } 2.5 \mathrm{~kW} \\
\text { focus on fuel } \\
\text { cell operation. }\end{array}$ & Nil & $2.5 \mathrm{~kW}$ & $\begin{array}{l}\text { Assembly } \rightarrow \\
\text { Operation } \rightarrow \text { life } \\
\text { end }\end{array}$ & $\begin{array}{l}\text { Emitted } 440 \mathrm{~g} \text { of } \\
\mathrm{CO}_{2 \mathrm{eq}} / \mathrm{kWh} .\end{array}$ & [63] \\
\hline & Nil & $\begin{array}{l}\text { A cross-scale } \\
\text { assessment } \\
\text { related to MCFC } \\
\text { system of } 500 \mathrm{Kw} \text {. }\end{array}$ & $\begin{array}{l}1 \mathrm{kWh} \text { of } \\
\text { electricity }\end{array}$ & $\begin{array}{l}\text { Fuel production } \rightarrow \\
\text { MCFC } \\
\text { Manufacturing } \rightarrow \\
\text { Operation } \rightarrow \\
\text { Maintenance }\end{array}$ & $0.549 \mathrm{~kg} \mathrm{CO} 2 \mathrm{eq} / \mathrm{kWh}$ & [64] \\
\hline & $\begin{array}{l}\text { Input gas is } \\
\text { natural gas. }\end{array}$ & Nil & $\begin{array}{l}1 \mathrm{kWh} \text { of } \\
\text { electricity }\end{array}$ & $\begin{array}{l}\text { Fuel processor } \rightarrow \\
\text { Power section } \rightarrow \\
\text { Power conditioning }\end{array}$ & $\begin{array}{l}\text { Need improvement in } \\
\text { hydrogen production } \\
\text { process. }\end{array}$ & [21] \\
\hline & $\begin{array}{l}\text { Decentralised } \\
\text { heat and } \\
\text { electricity } \\
\text { production. }\end{array}$ & Nil & $\begin{array}{l}1 \mathrm{kWh} \text { of } \\
\text { electricity }\end{array}$ & $\begin{array}{l}\text { Raw material } \rightarrow \\
\text { Material } \\
\text { manufacture } \rightarrow \\
\text { Product } \\
\text { manufacture } \rightarrow \\
\text { Use } \rightarrow \text { Disposal }\end{array}$ & $\begin{array}{l}\text { Positive outcomes } \\
\text { achieve when the } \\
\text { input gas is fuelled } \\
\text { with biogas rather than } \\
\text { natural gas. }\end{array}$ & [65] \\
\hline $\begin{array}{l}\text { Polymer } \\
\text { electrolyt } \\
\text { e } \\
\text { membra } \\
\text { ne type } \\
\text { (PEM) }\end{array}$ & $\begin{array}{l}\text { Analyse the } \\
\text { commercial } \\
\text { PEMFC micro- } \\
\text { CHP system } \\
\text { with the } \\
\text { reforcell system } \\
\text { and steam } \\
\text { reformer. }\end{array}$ & $\begin{array}{l}\text { Environmental } \\
\text { burdens of the } \\
\text { commercial } \\
\text { PEMFC micro-CHP } \\
\text { system. }\end{array}$ & $\begin{array}{l}5 \mathrm{~kW} \text { of } \\
\text { electricity }\end{array}$ & $\begin{array}{l}\text { Micro-CHP } \\
\text { production (Fuel } \\
\text { cell and stack, fuel } \\
\text { processor, balance } \\
\text { of plant) } \rightarrow \text { Use } \\
\text { (production of } \\
\text { replacement places } \\
\text { and treatment of } \\
\text { old ones) } \rightarrow \text { End of } \\
\text { life (treatment, } \\
\text { recycled, landfill) }\end{array}$ & $\begin{array}{l}\text { Reformer and boiler } \\
\text { contribute towards } \\
\text { GHG emissions. } \\
\text { The production, } \\
\text { maintenance and end- } \\
\text { of-life of the micro- } \\
\text { CHP are small } \\
\text { contributors towards } \\
\text { the impacts, excluding } \\
\text { human health. }\end{array}$ & [66] \\
\hline
\end{tabular}

Figure 7 shows the result of recent number of publications related to fuel cell study. The result was obtained from the Elsevier Database with the keywords "type of fuel cell for all studies" and "type of fuel cell with LCA". SOFC and PEMFC were the most interesting types of fuel cell that authors published from 2010 until 2020. Even though the number of fuel cell studies is more than a thousand, only $0.8 \%$ up to $3.4 \%$ of the publications focused on life cycle assessment. 


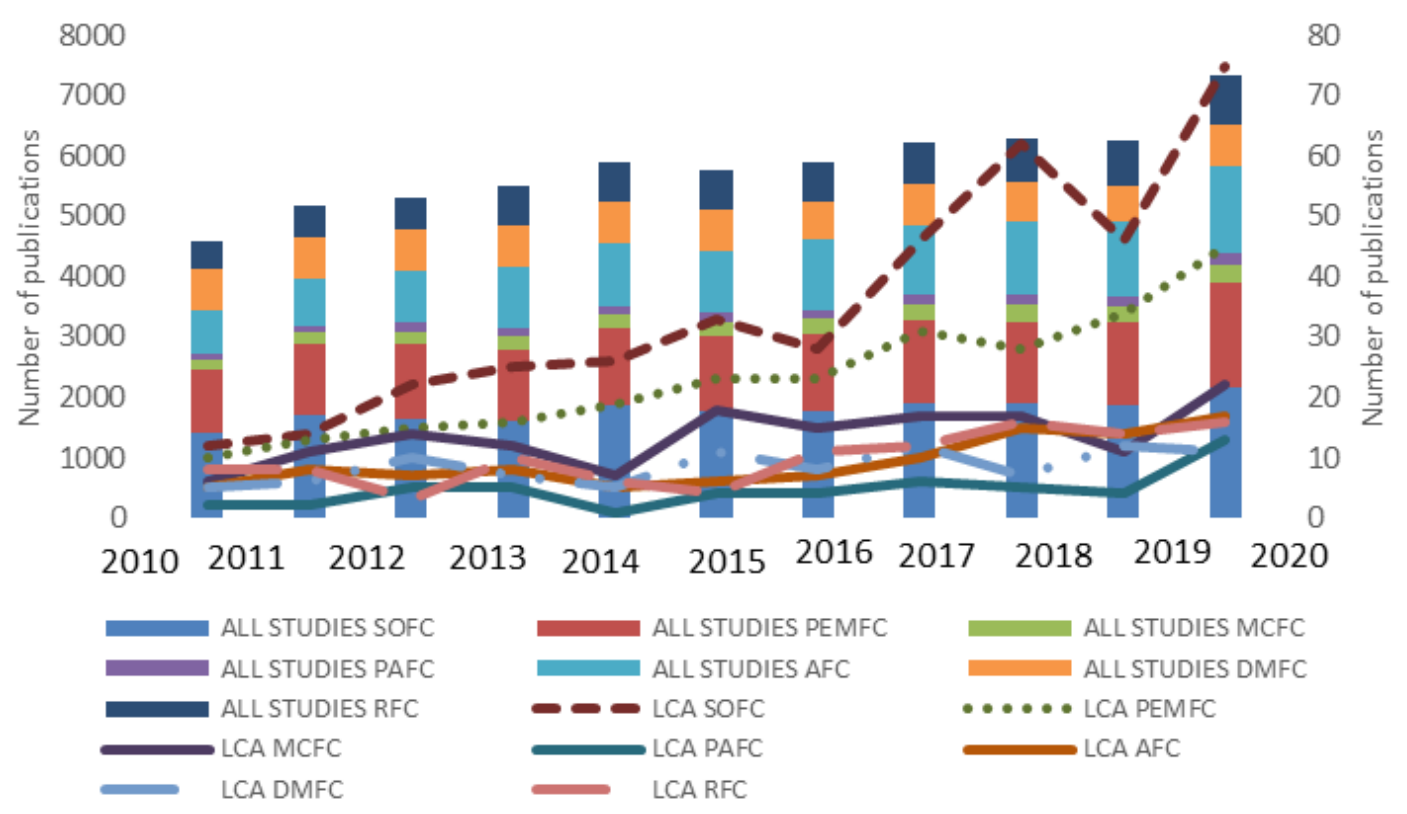

Fig. 7. Recent number of publications in fuel cell study

\section{Conclusion}

The fuel cell provides great potential for the future generation to produces electricity. Malaysia, as the country that produces abundant palm oil, creates a huge opportunity to utilising this gas to feed fuel cells. However, more research is needed in terms of its impact on the environment and the impending cost that will occur. Even Malaysia has such resources in producing biogas, the pioneering technology is still absent though. Biogas as an input to the fuel cell system seems to provide the vast potential to be explored. Hopefully, this paper can serve as a detailed guideline for other researchers in studying the life cycle assessment of biogas feed into the fuel cell. It also might as well be a base in exploring fuel cells in Malaysia. The application of fuel cells in electricity generation can reduce the dependency on fossil fuel. Concurrently, it can assist the government's achieving the target to consume $20 \%$ of RE in the electricity mix.

\section{Acknowledgments}

This research was financially supported by the Ministry of Higher Education Malaysia (FRGS14199/2018). The authors would like to express utmost gratitude to the reviewers and associate editor for their comments which have improvised this manuscript.

\section{References}

[1] Khattak, Muhammad Adil, Mohammad Azfar Haziq Ayoub, Muhammad Ariff Fadhlillah Abdul Manaf, Mohd Faidhi Mahru, Mohd Ridwan Mohd Juhari, Mira Idora Mustaffa, and Suhail Kazi. "Global energy security and European Union: A review." Journal of Advanced Research in Applied Sciences and Engineering Technology 11, no. 1 (2018): 64-81.

[2] Overton, Thomas. "World's largest fuel cell plant opens in South Korea." Power Magazine (2014).

[3] Chan, Siew Hwa, Jan Pawel Stempien, Ovi Lian Ding, Pei-Chen Su, and Hiang Kwee Ho. "Fuel cell and hydrogen technologies research, development and demonstration activities in Singapore-An update." International Journal of Hydrogen Energy 41, no. 32 (2016): 13869-13878. https://doi.org/10.1016/i.ijhydene.2016.05.192

[4] AFC. AFC energy for clean energy in Indonesia, in Fuel Cell Bulletin. Elsevier, 2007. https://doi.org/10.1016/S14642859(07)70313-9

[5] Saengprajak, Arnusorn, Aree Katcharoen, Wutthisat Chockua, and Jenjira Piamdee. "Prospective study of application the direct-biogas solid oxide fuel cell system to the biogas plant in Thailand." Energy Procedia 158 (2019): 978-983. https://doi.org/10.1016/i.egypro.2019.01.239 
[6] Stolten, P.D.D. National Strategies and Plans for Fuel Cells and Infrastructure. Energy Technology Network, 2014.

[7] Weidner, E., R. Ortiz Cebolla, and J. Davies. "Global deployment of large capacity stationary fuel cells." Tech. Rep (2019).

[8] Recalde, Mayra, Theo Woudstra, and P. V. Aravind. "Renewed sanitation technology: A highly efficient faecal-sludge gasification-solid oxide fuel cell power plant." Applied Energy 222 (2018): 515-529. https://doi.org/10.1016/i.apenergy.2018.03.175

[9] Bicer, Yusuf, and Farrukh Khalid. "Life cycle environmental impact comparison of solid oxide fuel cells fueled by natural gas, hydrogen, ammonia and methanol for combined heat and power generation." International Journal of Hydrogen Energy 45, no. 5 (2020): 3670-3685. https://doi.org/10.1016/i.ijhydene.2018.11.122

[10] Rillo, E., M. Gandiglio, A. Lanzini, S. Bobba, M. Santarelli, and G. Blengini. "Life cycle assessment (LCA) of biogas-fed solid oxide fuel cell (SOFC) plant." Energy 126 (2017): 585-602. https://doi.org/10.1016/i.energy.2017.03.041

[11] Prodromidis, George N., and Frank A. Coutelieris. "Thermodynamic analysis of biogas fed solid oxide fuel cell power plants." Renewable Energy 108 (2017): 1-10. https://doi.org/10.1016/i.renene.2017.02.043

[12] Cai, Weizi, Peipei Liu, Bin Chen, Haoran Xu, Zhijun Liu, Qian Zhou, Fangyong Yu et al. "Plastic waste fuelled solid oxide fuel cell system for power and carbon nanotube cogeneration." International Journal of Hydrogen Energy 44, no. 3 (2019): 1867-1876. https://doi.org/10.1016/i.ijhydene.2018.11.159

[13] Archer, Sophie A., and Robert Steinberger-Wilckens. "Systematic analysis of biomass derived fuels for fuel cells." international journal of hydrogen energy 43, no. $52 \quad$ (2018): 23178-23192. https://doi.org/10.1016/j.ijhydene.2018.10.161

[14] Gadsbøll, Rasmus Østergaard, Jesper Thomsen, Christian Bang-Møller, Jesper Ahrenfeldt, and Ulrik Birk Henriksen. "Solid oxide fuel cells powered by biomass gasification for high efficiency power generation." Energy 131 (2017): 198-206. https://doi.org/10.1016/i.energy.2017.05.044

[15] Nease, Jake, and Thomas A. Adams II. "Comparative life cycle analyses of bulk-scale coal-fueled solid oxide fuel cell power plants." Applied Energy 150 (2015): 161-175. https://doi.org/10.1016/i.apenergy.2015.03.105

[16] Ulusoy, Isilay, and Anatoli Dimoglo. "Electricity generation in microbial fuel cell systems with Thiobacillus ferrooxidans as the cathode microorganism." international journal of hydrogen energy 43, no. 2 (2018): 1171-1178. https://doi.org/10.1016/i.ijhydene.2017.10.155

[17] Yahya, Noor Fateen Afikah, Negar Dasineh Khiavi, and Norahim Ibrahim. "Green electricity production by Epipremnum Aureum and bacteria in plant microbial fuel cell." Journal of Advanced Research in Applied Sciences and Engineering Technology 5, no. 1 (2016): 22-31.

[18] Facci, Andrea L., and Stefano Ubertini. "Analysis of a fuel cell combined heat and power plant under realistic smart management scenarios." Applied Energy 216 (2018): 60-72. https://doi.org/10.1016/i.apenergy.2018.02.054

[19] Ghaffarpour, Z., M. Mahmoudi, A. H. Mosaffa, and L. Garousi Farshi. "Thermoeconomic assessment of a novel integrated biomass based power generation system including gas turbine cycle, solid oxide fuel cell and Rankine cycle." Energy conversion and management 161 (2018): 1-12. https://doi.org/10.1016/i.enconman.2018.01.071

[20] Perna, A., M. Minutillo, E. Jannelli, V. Cigolotti, S. W. Nam, and J. Han. "Design and performance assessment of a combined heat, hydrogen and power (CHHP) system based on ammonia-fueled SOFC." Applied Energy 231 (2018): 1216-1229. https://doi.org/10.1016/j.apenergy.2018.09.138

[21] Lunghi, Piero, Roberto Bove, and Umberto Desideri. "LCA of a molten carbonate fuel cell system." Journal of power sources 137, no. 2 (2004): 239-247. https://doi.org/10.1016/i.jpowsour.2004.06.005

[22] Pakdeechot, Siravit, Sherly Hanifarianty, and Makatar Wae-hayee. "The Effects of Sterilization Time of FFB on FruitBunch Separation and Crude Palm Oil Quality Using Direct Steaming." Journal of Advanced Research in Applied Mechanics 72, no. 1 (2020): 1-9. https://doi.org/10.37934/aram.72.1.19

[23] Aziz, Nur Izzah Hamna A., Marlia M. Hanafiah, and Shabbir H. Gheewala. "A review on life cycle assessment of biogas production: Challenges and future perspectives in Malaysia." Biomass and Bioenergy 122 (2019): 361-374. https://doi.org/10.1016/i.biombioe.2019.01.047

[24] Shafie, Shafini Mohd, Z. Othman, N. Hami, and S. Omar. "The Potential of using Biogas Feeding for Fuel Cells in Malaysia." International Journal of Energy Economics and Policy 10, no. 1 (2020): 109. https://doi.org/10.32479/ijeep.8373

[25] Aziz, Nur Izzah Hamna A., Marlia M. Hanafiah, Shabbir H. Gheewala, and Haikal Ismail. "Bioenergy for a cleaner future: A case study of sustainable biogas supply chain in the Malaysian Energy Sector." Sustainability 12, no. 8 (2020): 3213. https://doi.org/10.3390/su12083213

[26] Van Meijl, H., Edward Martinus Wilhelmus Smeets, Michiel van Dijk, J. P. Powell, and A. A. Tabeau. Macro-economic impact study for Bio-based Malaysia. LEI, part of Wageningen UR, 2012.

[27] Liu, Ting, Xiaoqin Zhou, Zifu Li, Xuemei Wang, and Jiachen Sun. "Effects of liquid digestate pretreatment on biogas production for anaerobic digestion of wheat straw." Bioresource technology 280 (2019): 345-351. https://doi.org/10.1016/i.biortech.2019.01.147 
[28] Aziz, Nur Izzah Hamna Abdul, Marlia M. Hanafiah, and Mohamed Yasreen Mohamed Ali. "Sustainable biogas production from agrowaste and effluents-A promising step for small-scale industry income." Renewable energy 132 (2019): 363-369. https://doi.org/10.1016/j.renene.2018.07.149

[29] Rogoff, Marc J., and Francois Screve. Waste-to-energy: technologies and project implementation. Academic Press, 2019. https://doi.org/10.1016/B978-0-12-816079-4.00002-5

[30] Li, Yebo, Stephen Y. Park, and Jiying Zhu. "Solid-state anaerobic digestion for methane production from organic waste." Renewable and sustainable energy reviews 15, no. 1 (2011): $821-826$. https://doi.org/10.1016/i.rser.2010.07.042

[31] Angelidaki, Irini, Dimitar Karakashev, Damien J. Batstone, Caroline M. Plugge, and Alfons JM Stams. "Biomethanation and its potential." Methods in enzymology 494 (2011): 327-351. https://doi.org/10.1016/B9780-12-385112-3.00016-0

[32] Pecchi, Matteo, and Marco Baratieri. "Coupling anaerobic digestion with gasification, pyrolysis or hydrothermal carbonization: A review." Renewable and Sustainable Energy Reviews 105 (2019): $462-475$. https://doi.org/10.1016/i.rser.2019.02.003

[33] Chen, Ye, Jay J. Cheng, and Kurt S. Creamer. "Inhibition of anaerobic digestion process: a review." Bioresource technology 99, no. 10 (2008): 4044-4064. https://doi.org/10.1016/i.biortech.2007.01.057

[34] Self, Stuart J., Bale V. Reddy, and Marc A. Rosen. "Review of underground coal gasification technologies and carbon capture." International Journal of Energy and Environmental Engineering 3, no. 1 (2012): 1-8. https://doi.org/10.1186/2251-6832-3-16

[35] Ng'andwe, Philimon, Jacob Mwitwa, and Ambayeba Muimba-Kankolongo. Forest policy, economics, and markets in Zambia. Academic Press, 2015.

[36] Chan, Wei Ping, Andrei Veksha, Junxi Lei, Wen-Da Oh, Xiaomin Dou, Apostolos Giannis, Grzegorz Lisak, and TeikThye Lim. "A novel real-time monitoring and control system for waste-to-energy gasification process employing differential temperature profiling of a downdraft gasifier." Journal of environmental management 234 (2019): 6574. https://doi.org/10.1016/i.jenvman.2018.12.107

[37] Sutardi, Tata, Manosh C. Paul, and Nader Karimi. "Investigation of coal particle gasification processes with application leading to underground coal gasification." Fuel 237 (2019): $1186-1202$. https://doi.org/10.1016/i.fuel.2018.10.058

[38] All Power Labs. Gasifier Types. 2021.

[39] Kelompok, Penghadam. "Production of biogas through anaerobic digestion of Cabomba furcata in digester batch system." Malaysian Journal of Analytical Sciences 20, no. 6 (2016): 1491-1497. https://doi.org/10.17576/mjas2016-2006-30

[40] Bong, Cassendra Phun Chien, Wai Shin Ho, Haslenda Hashim, Jeng Shiun Lim, Chin Siong Ho, William Soo Peng Tan, and Chew Tin Lee. "Review on the renewable energy and solid waste management policies towards biogas development in Malaysia." Renewable and Sustainable Energy Reviews 70 (2017): 988-998. https://doi.org/10.1016/i.rser.2016.12.004

[41] Loh, S. K., A. Nasrin, S. Mohamad Azri, B. Nurul Adela, and N. Muzzammil. "Biogas capture-A means of reducing greenhouse gas emissions from palm oil mill effluent." Oil Palm Bulletin 75 (2017): 27-36.

[42] Rahman, Md Mizanur, Mohd Faizal Hasan, Aminuddin Saat, and Mazlan Abdul Wahid. "Economics of biogas plants and solar home systems: For household energy applications." Journal of Advanced Research in Fluid Mechanics and Thermal Sciences 33, no. 1 (2017): 14-26.

[43] Mohd, MANSOR ISMAIL. "Renewable Energy Policy Status and Challenges of POME-Biogas Industry in Malaysia." Pertanika Journal of Scholarly Research Reviews 1, no. 1 (2015): 33-39.

[44] Hoo, Poh Ying, Haslenda Hashim, Wai Shin Ho, and Sie Ting Tan. "Potential biogas generation from food waste through anaerobic digestion in peninsular Malaysia." Chemical Engineering Transactions 56 (2017): 373-378.

[45] Abdullah, N., and F. Sulaiman. "The oil palm wastes in Malaysia." Biomass now-sustainable growth and use 1, no. 3 (2013): 75-93. https://doi.org/10.5772/55302

[46] Strazza, Carlo, Adriana Del Borghi, Paola Costamagna, Michela Gallo, Emma Brignole, and Paola Girdinio. "Life Cycle Assessment and Life Cycle Costing of a SOFC system for distributed power generation." Energy Conversion and Management 100 (2015): 64-77. https://doi.org/10.1016/i.enconman.2015.04.068

[47] Staffell, lain, and Andy Ingram. "Life cycle assessment of an alkaline fuel cell CHP system." International journal of hydrogen energy 35, no. 6 (2010): 2491-2505. https://doi.org/10.1016/j.ijhydene.2009.12.135

[48] Bhat, I. K., and Ravi Prakash. "LCA of renewable energy for electricity generation systems - a review." Renewable and sustainable energy reviews 13, no. 5 (2009): 1067-1073. https://doi.org/10.1016/i.rser.2008.08.004

[49] Rebitzer, Gerald, Tomas Ekvall, Rolf Frischknecht, Davis Hunkeler, Gregory Norris, Tomas Rydberg, W-P. Schmidt, Sangwon Suh, B. Pennington Weidema, and David W. Pennington. "Life cycle assessment: Part 1: Framework, goal 
and scope definition, inventory analysis, and applications." Environment international 30, no. 5 (2004): $701-720$. https://doi.org/10.1016/i.envint.2003.11.005

[50] Masoni, P., A. Zamagni, M. Bode, M. Finkbeiner, and K. Chomkhamsri. "Guidance Document for performing LCAs on Fuel Cells and $\mathrm{H}_{2}$ Technologies." (2011).

[51] Hijazi, O., S. Tappen, and M. Effenberger. "Environmental impacts concerning flexible power generation in a biogas production." Carbon Resources Conversion 2, no. 2 (2019): 117-125. https://doi.org/10.1016/i.crcon.2019.05.001

[52] Lin, Jiefeng, Callie W. Babbitt, and Thomas A. Trabold. "Life cycle assessment integrated with thermodynamic analysis of bio-fuel options for solid oxide fuel cells." Bioresource technology 128 (2013): $495-504$. https://doi.org/10.1016/i.biortech.2012.10.074

[53] Baratto, Francesco, and Urmila M. Diwekar. "Life cycle assessment of fuel cell-based APUs." Journal of Power Sources 139, no. 1-2 (2005): 188-196. https://doi.org/10.1016/i.jpowsour.2004.07.025

[54] Lee, Young Duk, Kook Young Ahn, Tatiana Morosuk, and George Tsatsaronis. "Environmental impact assessment of a solid-oxide fuel-cell-based combined-heat-and-power-generation system." Energy 79 (2015): $455-466$. https://doi.org/10.1016/i.energy.2014.11.035

[55] Mehmeti, Andi, Stephen J. McPhail, Davide Pumiglia, and Maurizio Carlini. "Life cycle sustainability of solid oxide fuel cells: From methodological aspects to system implications." Journal of Power Sources 325 (2016): $772-785$. https://doi.org/10.1016/i.jpowsour.2016.06.078

[56] Strazza, C., A. Del Borghi, P. Costamagna, A. Traverso, and M. Santin. "Comparative LCA of methanol-fuelled SOFCs as auxiliary power systems on-board ships." Applied Energy 87, no. 5 (2010): 1670-1678. https://doi.org/10.1016/j.apenergy.2009.10.012

[57] Häfele, S., M. Hauck, and J. Dailly. "Life cycle assessment of the manufacture and operation of solid oxide electrolyser components and stacks." International Journal of Hydrogen Energy 41, no. 31 (2016): 13786-13796. https://doi.org/10.1016/j.ijhydene.2016.05.069

[58] Kawajiri, Kotaro, and Tsutomu Inoue. "Cradle-to-gate greenhouse gas impact of nanoscale thin-film solid oxide fuel cells considering scale effect." Journal of Cleaner Production 112 (2016): 4065-4070. https://doi.org/10.1016/i.jclepro.2015.05.138

[59] Ramadhani, F., Mohd Azlan Hussain, Hazlie Mokhlis, and S. Hajimolana. "Optimization strategies for Solid Oxide Fuel Cell (SOFC) application: A literature survey." Renewable and Sustainable Energy Reviews 76 (2017): 460-484. https://doi.org/10.1016/i.rser.2017.03.052

[60] Casas, Yannay, Jo Dewulf, Luis E. Arteaga-Pérez, Mayra Morales, Herman Van Langenhove, and Elena Rosa. "Integration of Solid Oxide Fuel Cell in a sugar-ethanol factory: analysis of the efficiency and the environmental profile of the products." Journal of Cleaner Production 19, no. 13 (2011): 1395-1404. https://doi.org/10.1016/j.jclepro.2011.04.018

[61] Smith, Lucy, Taofeeq Ibn-Mohammed, Fan Yang, lan M. Reaney, Derek C. Sinclair, and SC Lenny Koh. "Comparative environmental profile assessments of commercial and novel material structures for solid oxide fuel cells." Applied Energy 235 (2019): 1300-1313. https://doi.org/10.1016/j.apenergy.2018.11.028

[62] Karakoussis, V., N. P. Brandon, M. Leach, and R. Van der Vorst. "The environmental impact of manufacturing planar and tubular solid oxide fuel cells." Journal of Power Sources 101, no. 1 (2001): 10-26. https://doi.org/10.1016/S0378-7753(01)00482-7

[63] Monaco, A., and U. Di Matteo. "Life cycle analysis and cost of a molten carbonate fuel cell prototype." International journal of hydrogen energy 36, no. 13 (2011): 8103-8111. https://doi.org/10.1016/j.ijhydene.2011.01.106

[64] Mehmeti, Andi, Juan Pedro Pérez-Trujillo, Francisco Elizalde-Blancas, Athanasios Angelis-Dimakis, and Stephen J. McPhail. "Exergetic, environmental and economic sustainability assessment of stationary Molten Carbonate Fuel Cells." Energy Conversion and Management $168 \quad$ (2018): https://doi.org/10.1016/i.enconman.2018.04.095

[65] Mehmeti, Andi, Francesca Santoni, Massimiliano Della Pietra, and Stephen J. McPhail. "Life cycle assessment of molten carbonate fuel cells: State of the art and strategies for the future." Journal of Power Sources 308 (2016): $97-$ 108. https://doi.org/10.1016/j.jpowsour.2015.12.023

[66] Di Marcoberardino, Gioele, Giampaolo Manzolini, Cécile Guignard, and Violaine Magaud. "Optimization of a microCHP system based on polymer electrolyte membrane fuel cell and membrane reactor from economic and life cycle assessment point of view." Chemical Engineering and Processing-Process Intensification 131 (2018): 70-83. https://doi.org/10.1016/i.cep.2018.06.003 